\title{
Human CD4 T-Cells With a Naive Phenotype Produce Multiple Cytokines During Mycobacterium Tuberculosis Infection and Correlate With Active Disease
}

\section{OPEN ACCESS \\ Edited by: \\ Steffen Stenger, \\ Universitätsklinikum Ulm \\ Germany}

Reviewed by:

Maria Florencia Quiroga, Universidad de Buenos

Aires, Argentina

Stephanie Wehrstedt, Universitätsklinikum UIm,

Germany

*Correspondence:

Francesco Dieli

francesco.dieli@unipa.it;

Nadia Caccamo

nadia.caccamo@unipa.it

tThese authors have contributed equally to this work.

₹Joint senior authors on this work.

Specialty section:

This article was submitted to Microbial Immunology,

a section of the journal

Frontiers in Immunology

Received: 20 February 2018 Accepted: 03 May 2018

Published: 23 May 2018

Citation:

Orlando V, La Manna MP, Goletti D, Palmieri F, Lo Presti E, Joosten SA, La Mendola C, Buccheri S, Ottenhoff THM, Dieli F and Caccamo N (2018) Human CD4 T-Cells With a Naive Phenotype Produce Multiple Cytokines During Mycobacterium Tuberculosis Infection and Correlate With Active Disease.

Front. Immunol. 9:1119. doi: 10.3389/fimmu.2018.01119

\begin{abstract}
Valentina Orlando ${ }^{1,2 \dagger}$, Marco P. La Manna ${ }^{1,2+}$, Delia Goletti ${ }^{3}$, Fabrizio Palmieri ${ }^{3}$, Elena Lo Presti ${ }^{1,2}$, Simone A. Joosten ${ }^{4}$, Carmela La Mendola ${ }^{2}$, Simona Buccheri ${ }^{5}$, Tom H. M. Ottenhoff ${ }^{4}$, Francesco Dieli ${ }^{1,2 *}$ and Nadia Caccamo ${ }^{1,2 * \neq}$

Central Laboratory of Advanced Diagnosis and Biomedical Research (CLADIBIOR), University of Palermo, Palermo, Italy, ${ }^{2}$ Department of Biopathology, University of Palermo, Palermo, Italy, ${ }^{3}$ Translational Research Unit, National Institute for Infectious Diseases L. Spallanzani, Rome, Italy, ${ }^{4}$ Department of Infectious Diseases, Leiden University Medical Center, Leiden, Netherlands, ${ }^{5}$ Istituto Mediterraneo per i Trapianti e Terapie ad Alta Specializzazione, Palermo, Italy
\end{abstract}

T-cell-mediated immune responses play a fundamental role in controlling Mycobacterium tuberculosis (M. tuberculosis) infection, and traditionally, this response is thought to be mediated by Th1-type CD4+ T-cells secreting IFN- $\gamma$. While studying the function and specificity of $M$. tuberculosis-reactive CD4+ T-cells in more detail at the single cell level; however, we found a human CD4+ T-cell population with a naive phenotype that interestingly was capable of producing multiple cytokines ( $T_{\text {CNP }}$ cells). CD4 ${ }^{+} T_{\text {CNP }}$ cells phenotyped as $\mathrm{CD}^{2} 5^{10} \mathrm{CD} 28^{\text {int }} \mathrm{CD} 49 \mathrm{~d}^{\text {hi }} \mathrm{CXCR} 3^{\text {hi }}$ and showed a broad distribution of $T$ cell receptor $\mathrm{V} \beta$ segments. They rapidly secreted multiple cytokines in response to different $M$. tuberculosis antigens, their frequency was increased during active disease, but was comparable to latent tuberculosis infection in treated TB patients. These results identify a novel human CD4+ T-cell subset involved in the human immune response to mycobacteria, which is present in active TB patients' blood. These results significantly expand our understanding of the immune response in infectious diseases.

Keywords: CD4 T-cells, naive cells, Mycobacterium tuberculosis, tuberculosis, cytokines

\section{INTRODUCTION}

Several studies in experimental mouse models and in HIV-infected patients have underscored the essential role of $\mathrm{CD} 4^{+} \mathrm{T}$-cells and Th1 immunity in protection against tuberculosis (TB) (1). Moreover, $\mathrm{CD} 4^{+} \mathrm{T}$-cells producing one, two, or three cytokines (polyfunctional $\mathrm{T}$ cells) have been linked to bacterial load and disease activity in humans, as well as to protective TB to vaccine-induced responses in animal models of TB (2-4). Protective immune responses against mycobacterial infection are thought to be dependent on quality, as measured by the capacity of $\mathrm{T}$ cells to exert multiple

Abbreviations: M. tuberculosis, mycobacterium tuberculosis; $\mathrm{TB}$, tuberculosis; $\mathrm{T}_{\mathrm{CNP}}$ cells, cytokine-producing $\mathrm{T}$ cells with a naïve phenotype. 
functions, rather than on their magnitude, which is predominantly related to the frequency of antigen-specific $\mathrm{T}$ cells with a particular effector function $(5,6)$.

Detection of antigen-specific cytokine production in individual $\mathrm{T}$ cells by intracellular cytokine staining and flow cytometry has been widely used to identify specific subsets of $\mathrm{T}$ cells producing different types of cytokines and to correlate their cytokine production patterns with functional phenotypes according to the expression of surface markers.

$\mathrm{CD}^{+}{ }^{+} \mathrm{T}$-cells can be divided into at least three different populations: naive $\left(\mathrm{T}_{\mathrm{N}}\right)$ referred to as $\mathrm{CD} 45 \mathrm{RA}^{+} \mathrm{CCR} 7^{+}$, central memory $\left(\mathrm{T}_{\mathrm{CM}}\right)$ as $\mathrm{CD} 4 \mathrm{R}^{-} \mathrm{CCR} 7^{+}$and effector memory $\left(\mathrm{T}_{\mathrm{EM}}\right)$ as $\mathrm{CD} 4 \mathrm{RA}^{-} \mathrm{CCR} 7^{-}$. $\mathrm{T}_{\mathrm{EM}}$ cells rapidly respond to re-encounter of antigen, such as in re-infection, whereas $\mathrm{T}_{\mathrm{CM}}$ cells are long-lived $\mathrm{T}$ cells with self-renewal and a homeostatic proliferative capacity that might contribute to their maintenance (7). In several infection models, including $\mathrm{TB}, \mathrm{T}_{\mathrm{EM}}$ cells are expanded during active bacillary replication, while $\mathrm{T}_{\mathrm{CM}}$ cells are mostly detectable after control and eradication of infection $(4,8)$, indicating that distinct memory phenotypes and functions are associated with different stages of infection.

In the present study, we performed a broad phenotypic and functional characterization of $M$. tuberculosis-specific $\mathrm{CD}^{+}$ $\mathrm{T}$-cells to evaluate whether distinct $\mathrm{T}$ cell functional signatures could be correlated with cell surface memory and effector phenotypes in the different phases of infection and disease.

We used additional surface markers, such as CD28 and CD95, which allow the identification of six $\mathrm{CD} 4^{+} \mathrm{T}$ cell subsets in the peripheral blood of healthy human beings (9). Moreover, we analyzed the expression of other molecules mediating lymphocyte functions, including the CD49d integrin and the CXCR3 chemokine receptor, which is expressed on IFN- $\gamma$-producing Th1 cells and allows cells to traffic rapidly to inflamed tissues. Unexpectedly, this approach revealed the existence of a novel human $\mathrm{CD}^{+} \mathrm{T}$ cell subset in $\mathrm{TB}$, which is antigen specific, associated with disease activity, and expresses an undescribed phenotype, which explains why these cells have not been detected.

\section{MATERIALS AND METHODS}

\section{Human Subjects}

Peripheral blood was obtained from 18 adults with pulmonary TB disease (Table 1) recruited from the National Institute for Infectious diseases L. Spallanzani (INMI) in Rome. The majority of TB patients had been vaccinated with bacillus CalmetteGuérin, none had evidence of HIV infection, or was being treated with steroid or other immunosuppressive. Active TB microbiologically diagnosed was defined based on the M. tuberculosis isolation from sputum culture. All patients were treated in accordance with Italian guidelines and received therapy for 6 months. Treatment was successful in all participants, as evidenced by the absence of any clinical or radiographic evidence of recurrent disease and sterile mycobacterial cultures at the end of treatment. Peripheral blood from patients was collected within 8 days of specific treatment initiation and, in some patients, after completion of chemotherapy (TB-6). Latent tuberculosis
TABLE 1 | Characteristics of enrolled patients.

\begin{tabular}{|c|c|c|c|c|}
\hline & Active TB & LTBI & Past TB & Total \\
\hline$N(\%)$ & $18(51.4)$ & 7 (20.0) & 10 (28.6) & 35 (100.0) \\
\hline $\begin{array}{l}\text { Age median } \\
(\mathrm{IQR})\end{array}$ & $39(29.0-43.5)$ & $37(28.0-63.0)$ & $44.5(34.0-51.0)$ & $41(29.0-45.0)$ \\
\hline
\end{tabular}

Sex

$\begin{array}{lllll}\text { Female } N(\%) & 5(27.8) & 3(42.9) & 6(60.0) & 14(40.0)\end{array}$

Origin

West Europe (\%) $\quad 2(11.1) \quad 4(57.1) \quad 2(20.0) \quad 8(22.9)$

East Europe (\%) $\quad 10(55.6) \quad 1(14.3) \quad 5(50.0) \quad 16(45.7)$

$\begin{array}{lllll}\text { Asia }(\%) & 2(11.1) & - & - & 2(5.7)\end{array}$

Africa (\%) $\quad 3(16.7) \quad 1(14.3) \quad 1(10.0) \quad 5(14.3)$

South America $\quad 1(5.6) \quad 1(14.3) \quad 2(20.0) \quad 4(11.4)$

BCG

$\begin{array}{lllll}\text { Vaccinated (\%) } & 16(88.9) & 3(42.9) & 8(80.9) & 27(77.1)\end{array}$

QFT-IT

Positive (\%)

Negative (\%)

Not done (\%)

Microbiological

TB (\%)

TB, tuberculosis; LTBI, latent tuberculosis infection; BCG, bacillus Calmette-Guérin; $I Q R$, interquartile range; GTF, QuantiFERON-TB GOLD In-tube.

infection (LTBI) individuals reported household or equivalent close contact (work) with smear-positive pulmonary TB patients in the previous 3 months, and scored positive in QuantiFERON Gold In-Tube (QFT IT, Qiagen) with no active TB lesions at chest radiography and had not received any prior preventive therapy $(10,11)$. Table 1 reports the characteristics of the enrolled subjects included in this study. The study was approved by the Ethical Committee of the University Hospital in Palermo (approval number 13/2013) and of INMI, approval number 72/2015. Informed written consent was provided by all participants.

\section{Short-Term In Vitro Stimulation and Intracellular FACS Analysis}

Peripheral blood was collected in heparin tubes, and peripheral blood mononuclear cells (PBMC) were isolated by FicollHypaque density gradient centrifugation (Euroclone). Recovered PBMCs were counted using a hemocytometer and viability, as tested by trypan blue exclusion, was always $>95 \%$. Peptide pools covering the whole sequences of ESAT-6 and CFP-10 M. tuberculosis proteins were used, as well as recombinant Ag85B and Acr proteins expressed in Escherichia coli and purified as previously described (12). PBMCs $\left(10^{6} / \mathrm{mL}\right)$ were stimulated with $M$. tuberculosis antigens at a final concentration of $10 \mu \mathrm{g} / \mathrm{mL}$ or Ionomycin (Sigma, St. Louis, MO, USA, $1 \mu \mathrm{g} / \mathrm{mL}$ final concentration) and phorbolmyristate acetate (PMA, Sigma, $150 \mathrm{ng} / \mathrm{mL}$ final concentration). Cells were cultured in a humidified incubator at $37^{\circ} \mathrm{C}$ with $5 \% \mathrm{CO}_{2}$ for $6 \mathrm{~h}$ in the presence of $5 \mu \mathrm{g} / \mathrm{mL}$ Brefeldin A (Sigma, St. Louis, MO, USA). Following incubation, PBMCs were harvested, washed in PBS containing $1 \%$ FCS and $0.1 \%$ sodium azide, and then stained with the antibodies (Table S1 in Supplementary Material) in incubation buffer (PBS- $1 \%$ FCS- $0.1 \% \mathrm{Na}$ azide) for $30 \mathrm{~min}$ at $4^{\circ} \mathrm{C}$, as indicated by Cossarizza et al. (13). 
Subsequently, PBMCs were washed, fixed, and permeabilized (Cytofix/Cytoperm Kit, BD Pharmingen) according to the manufacturer's instructions and stained for intracellular cytokines with conjugated anti-IFN- $\gamma$, anti-IL-2 and TNF- $\alpha$ mAbs (see Table $\mathrm{S} 1$ in Supplementary Material). Isotype-matched control mAbs were used. All mAbs were from BD Pharmingen (San Josè, CA, USA). Cells were washed, fixed in $1 \%$ paraformaldehyde, and at least $1 \times 10^{6}$ lymphocytes were acquired using a FACSARIA I (BD Biosciences), following gating according to forward and side scatter plots. FACS plots were analyzed using FlowJo software (version 6.1.1; Tree Star, Ashland, OR, USA).

The median background staining level observed in the medium control was $0.02 \%$ based on viable $\mathrm{CD}^{+}$lymphocytes for IFN- $\gamma$. A detected antigen-specific response was defined as a response where the percentage of cytokine-positive $\mathrm{CD} 4^{+}$lymphocytes was at least twofold above the background observed in the medium control and at the difference between specific response and background level being $>0.01 \%$.

The experiments of in vitro stimulation were performed on a median PBMC cell count of $1.5 \times 10^{6}$ cells with a minimum of $9 \times 10^{5}$ viable cells upon Ficoll-Hypaque recovery and a maximum of $1.7 \times 10^{6}$ cells being acquired. A minimum of $5 \times 10^{5}$ $\mathrm{CD}^{+} \mathrm{T}$ cells were acquired on the viable lymphocyte gate and population of IFN- $\gamma^{+} \mathrm{CD} 4^{+} \mathrm{T}$ cells more than 50 cells were considered for further analysis.

\section{FACS Analysis of the TCR-V $\beta$ Repertoire}

The IOTest Beta Mark TCR-V $\beta$ Repertoire kit (Beckman Coulter, Miami, FL, USA) was used for the assessment of the following TCR-V $\beta$ regions: $V \beta 1, V \beta 2, V \beta 3, V \beta 4, V \beta 5.1, V \beta 5.2, V \beta 5.3$, $\mathrm{V} \beta 7.1, \mathrm{~V} \beta 7.2, \mathrm{~V} \beta 8, \mathrm{~V} \beta$ 9, V $\beta 11, \mathrm{~V} \beta 12, \mathrm{~V} \beta 13.1, \mathrm{~V} \beta 13.2, \mathrm{~V} \beta 13.6$, $\mathrm{V} \beta 14, \mathrm{~V} \beta 16, \mathrm{~V} \beta 17, \mathrm{~V} \beta 18, \mathrm{~V} \beta 20, \mathrm{~V} \beta 21.3, \mathrm{~V} \beta 22$, and $\mathrm{V} \beta 23$. This kit includes 8 cocktails, each containing antibodies against 3 different TCR-V $\beta$ regions covering a total of 24 TCR-V $\beta$ regions and approximately $70 \%$ of the normal human TCR-V $\beta$ repertoire. In performing the TCR-V $\beta$ repertoire assay, anti-IFN- $\gamma$ APC, anti-CD3 BV510, anti-CD4 PercPCy5.5, anti-CD45RA BV450, and anti-CCR7 PECy7 were added to the $8 \mathrm{~V} \beta$ cocktails. TCR$\mathrm{V} \beta$ antigen usage was analyzed by using general gating strategies based on amine-reactive LIVE/DEAD fixable NIR dead cells exclusion. Selected T-cell populations per each gating strategy were analyzed for TCR-V $\beta$ expression and quantitation. The values were compared to published normal ranges provided by the manufacturer.

\section{Spanning-Tree Progression Analysis of Density-Normalized Events (SPADE) Analysis}

FACS plots (FCS files) were first analyzed by FlowJo and upon gating performed as above described, a new FCS file was generated (exported.FCS3.fcs), which was imported into the SPADE software. SPADE clustering algorithm on the https://Cytobank. org platform was performed in four steps as described by Qiu et al. (14): (a) density-dependent downsampling to equalize the density in the point cloud of cells, (b) agglomerative clustering to partition the point cloud of cells into cell clusters, (c) minimum spanning tree construction to link the cell clusters, and (d) up sampling to map all the cells onto the resulting tree structure. A detailed description of each step is found in Ref. (14). SPADE analysis was performed to visualize single cells, among live $\mathrm{CD}^{+} \mathrm{CD}^{+}$lymphocytes from all patients with active TB. The nodes of the tree reproduce clusters of cells that are similar in terms of marker expression, the color indicates intensity of the different marker staining, presented as arbitrary relative median fluorescence intensity and indicated with a heat map. This tree is constituted by an interconnected cluster of nodes, or clusters of connected nodes, which correspond with phenotypically defined CD4 $\mathrm{T}$ cell populations. SPADE uses the size and color of each node to signify the number of cells and median marker expression, respectively.

\section{Statistical Analysis}

Statistical significance ( $p$ values) of the magnitude of responses was calculated with unpaired two-tailed Student's $t$-test. Kruskal-Wallis and Mann-Whitney test were used as non parametric test. Data were analyzed using statistical software SYSTAT 11 (Systat Software) or Graph Pad Prism (4.02) (Graph Pad Software).

\section{RESULTS}

\section{IFN- $\gamma$ Production by M. tuberculosis- Specific CD4 T-Cells With a Naive Phenotype}

Peripheral blood mononuclear cells from patients with active TB disease, were stimulated for $6 \mathrm{~h}$ with a pool of peptides spanning the whole sequences of M. tuberculosis ESAT- 6 and CFP-10 antigens and assessed for intracellular interferon- $\gamma$ (IFN- $\gamma$ ). We then performed flow cytometric analyses to determine memory subset phenotypes of antigen-specific $\mathrm{CD} 4^{+} \mathrm{T}$-cells, based on their expression of CCR7 and CD45RA (7) (Figures 1A,B). As expected, the majority $(\sim 60 \%)$ of IFN $-\gamma^{+} \mathrm{CD} 4^{+} \mathrm{T}$-cells responding to ESAT-6/CFP-10 in patients with active TB disease lacked surface expression of CD45RA and CCR7, compatible with a $\mathrm{T}_{\mathrm{EM}}$ phenotype, while $10-28 \%$ of IFN- $\gamma^{+}$ $\mathrm{CD}^{+}$T-cells expressed CCR7 but not CD45RA, consistent with a $\mathrm{T}_{\mathrm{CM}}$ phenotype. However, and surprisingly, a sizeable yet variable fraction $(5-24 \%)$ of $\mathrm{CD}^{+} \mathrm{T}$-cells responding to ESAT6/CFP-10 in patients with active TB disease had a naive $\left(\mathrm{T}_{\mathrm{N}}, \mathrm{CD} 45 \mathrm{RA}^{+} \mathrm{CCR} 7^{+}\right)$membrane expression phenotype. Figure $1 \mathrm{~A}$ shows the gating strategy used to select $\mathrm{CD} 4^{+} \mathrm{T}$ cells and comprise of sequential gating, dump channel (excluding dead cells, CD19 and CD14 cells) vs $\mathrm{CD}^{+}$, single live cells, and $\mathrm{CD} 4^{+}$vs IFN $-\gamma^{+}$cells, and Figure $1 \mathrm{~B}$ shows cumulative data of the phenotype distribution of IFN- $\gamma$-producing $\mathrm{CD} 4^{+} \mathrm{T}$ cells from 18 patients with active TB disease. To better define this population of $\mathrm{CD} 4^{+} \mathrm{T}$-cells with an apparent naive phenotype that nevertheless produced IFN- $\gamma$ in response to $M$. tuberculosis antigens, expression of CD95, CD49d, CXCR3, and CD28 by different subsets of IFN- $\gamma^{+} \mathrm{CD} 4^{+} \mathrm{T}$ cells was compared to bulk (IFN- $\gamma^{-}$cells) $\mathrm{T}_{\mathrm{N}}, \mathrm{T}_{\mathrm{CM}}$, and $\mathrm{T}_{\mathrm{EM}}$ cells (Figure 2 ). Virtually, all $M$. tuberculosis-specific IFN- $\gamma^{+} \mathrm{CD} 4^{+}$T-cells expressed 

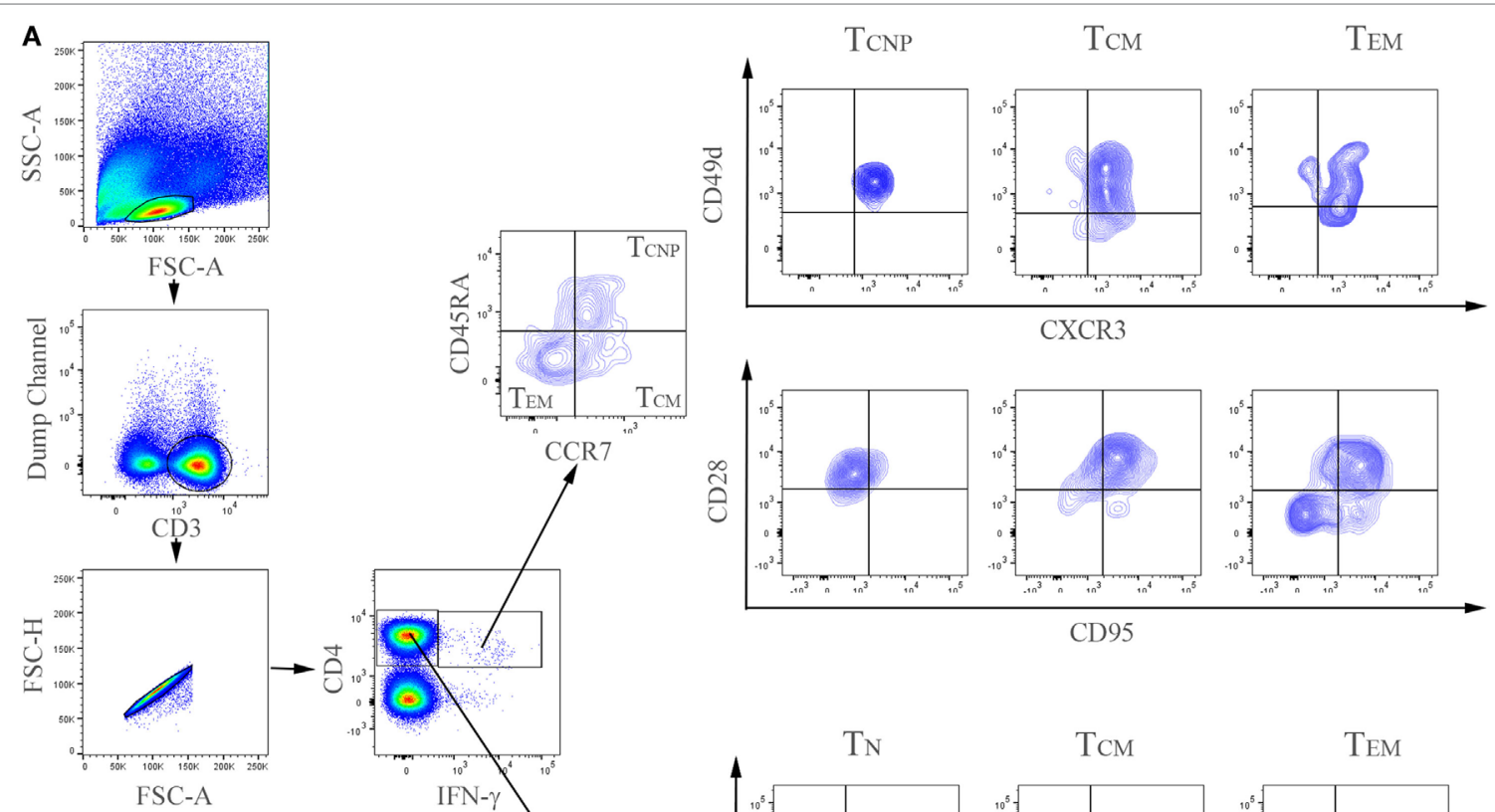

CXCR3
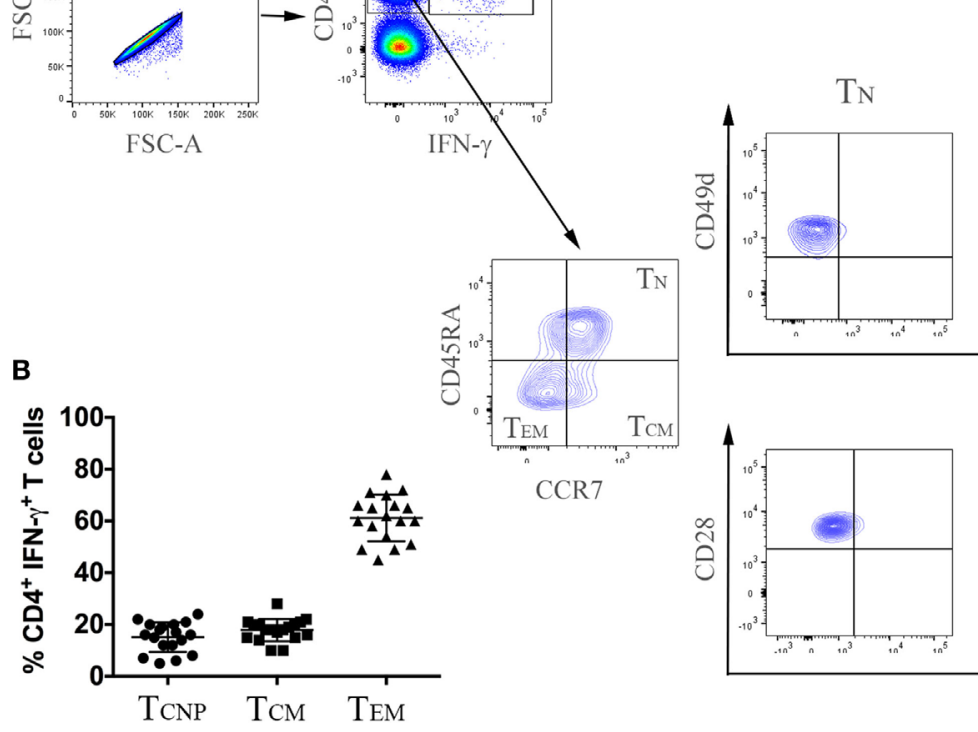

TCM

TEM
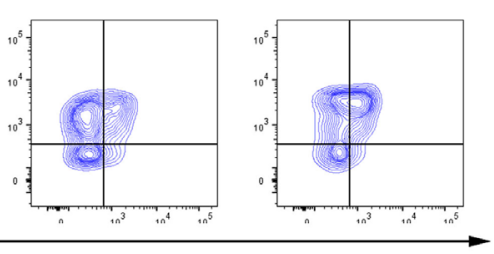

CXCR3
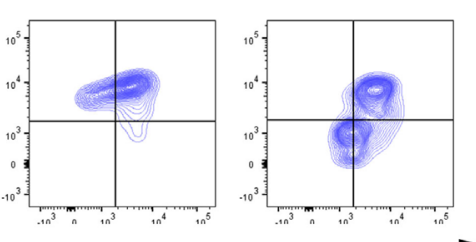

CD95

FIGURE 1 | Expansion of CD4 $4^{+}$T-cells with a naive phenotype (CD4 ${ }^{+} T_{\text {CNP }}$ cells) in patients with active TB. (A) Flow cytometry analysis of peripheral blood mononuclear cells (PBMC) from one representative TB patient. PBMCs were stimulated with ESAT-6/CFP-10 peptides for $6 \mathrm{~h}$ as described under Section "Materials and Methods." Cells were acquired by a FACSAria I and were gated according to the illustration, as follows: initial gate on dump channel (excluding dead cells, CD19, and CD14 cells) vs $\mathrm{CD}^{+}$, single live cells, and CD4+ vs IFN- $\gamma$ cells. M. tuberculosis-specific (CD4+IFN- $\left.\gamma^{+}\right)$and bulk (CD4+IFN- $\left.\gamma^{-}\right)$cells were further distinguished in $T_{\mathrm{CNP}}, T_{\mathrm{N}}, \mathrm{T}_{\mathrm{CM}}$, and $\mathrm{T}_{\mathrm{EM}}$ based on differential expression of CD45RA and CCR7, CD28, CD49d, CD95 and CXCR3 expression was finally evaluated on these differentially-gated populations. (B) Cumulative data on the frequencies of ESAT-6/CFP-10-specific CD4 ${ }^{+} \mid \mathrm{FN}-\gamma^{+} \mathrm{T}_{\mathrm{CNP}}\left(\mathrm{CD} 45 \mathrm{RA}{ }^{+} \mathrm{CCR} 7^{+} \mathrm{CD} 28^{+}\right.$,

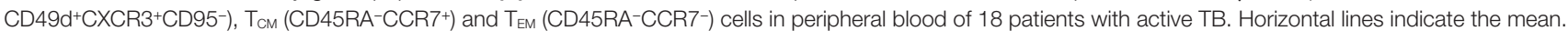

CD28, CD49d, with relatively large proportions also expressing CXCR3, only a very small proportion of $\mathrm{CD}^{+} \mathrm{T}_{\mathrm{CNP}}$ cells expressed CD95. Therefore, and with the exception of CD95, the phenotypic profile of IFN- $\gamma^{+} \mathrm{CD} 4^{+} \mathrm{T}_{\mathrm{N}}$-cells was comparable to that of IFN- $\gamma^{+} \mathrm{CD} 4^{+} \mathrm{T}_{\mathrm{CM}}$ and $\mathrm{T}_{\mathrm{EM}}$ cells. Compared to bulk CD4 ${ }^{+}$ $\mathrm{T}_{\mathrm{N}}$ cells, IFN $\gamma^{+} \mathrm{CD} 4^{+} \mathrm{T}$-cells with the naive surface phenotype could be distinguished by differential expression of CXCR3, with the latter containing a significantly larger proportion of cells expressing CXCR3 (median $=65 \%$ ), while this was barely detectable in the former (median $=5 \%$ ).

Thus, this analysis identifies a phenotypically naïve, ESAT-6/ CFP-10-specific, IFN- $\gamma^{+} \mathrm{CD} 4^{+} \mathrm{CD} 45 \mathrm{RA}^{+} \mathrm{CCR} 7^{+}$population that expresses cell surface $\mathrm{CD} 95^{+} \mathrm{CD} 28^{+} \mathrm{CD} 49 \mathrm{~d}^{+} \mathrm{CXCR} 3^{+}$. These
$\mathrm{CD}^{+}{ }^{+} \mathrm{T}$-cells with a naive phenotype but producing cytokines were designated $\mathrm{T}_{\mathrm{CNP}}$ cells (cells with naive phenotype that are able to produce cytokines).

In $5 / 18$ patients with active TB disease, we detected two different populations of IFN- $\gamma$-producing $\mathrm{CD}^{+} \mathrm{T}$ cells, one IFN$\gamma^{\text {high }}$ and one IFN- $\gamma^{\text {low }}$ : as shown in Figure S1 in Supplementary Material, the IFN- $\gamma^{\text {low }}$ CD 4 T-cells coincided with the $\mathrm{T}_{\mathrm{CNP}}$ population, while the IFN- $\gamma^{\text {high }} \mathrm{CD} 4^{+} \mathrm{T}$ cell population predominantly expressed a $\mathrm{T}_{\mathrm{EM}}$ phenotype.

To better define the IFN- $\gamma$ profiles of CD $4 \mathrm{~T}_{\mathrm{CNP}}$ cells, we used the SPADE algorithm, which distinguishes cell subsets by clustering, based on surface antigen expression identified by a color gradient. 


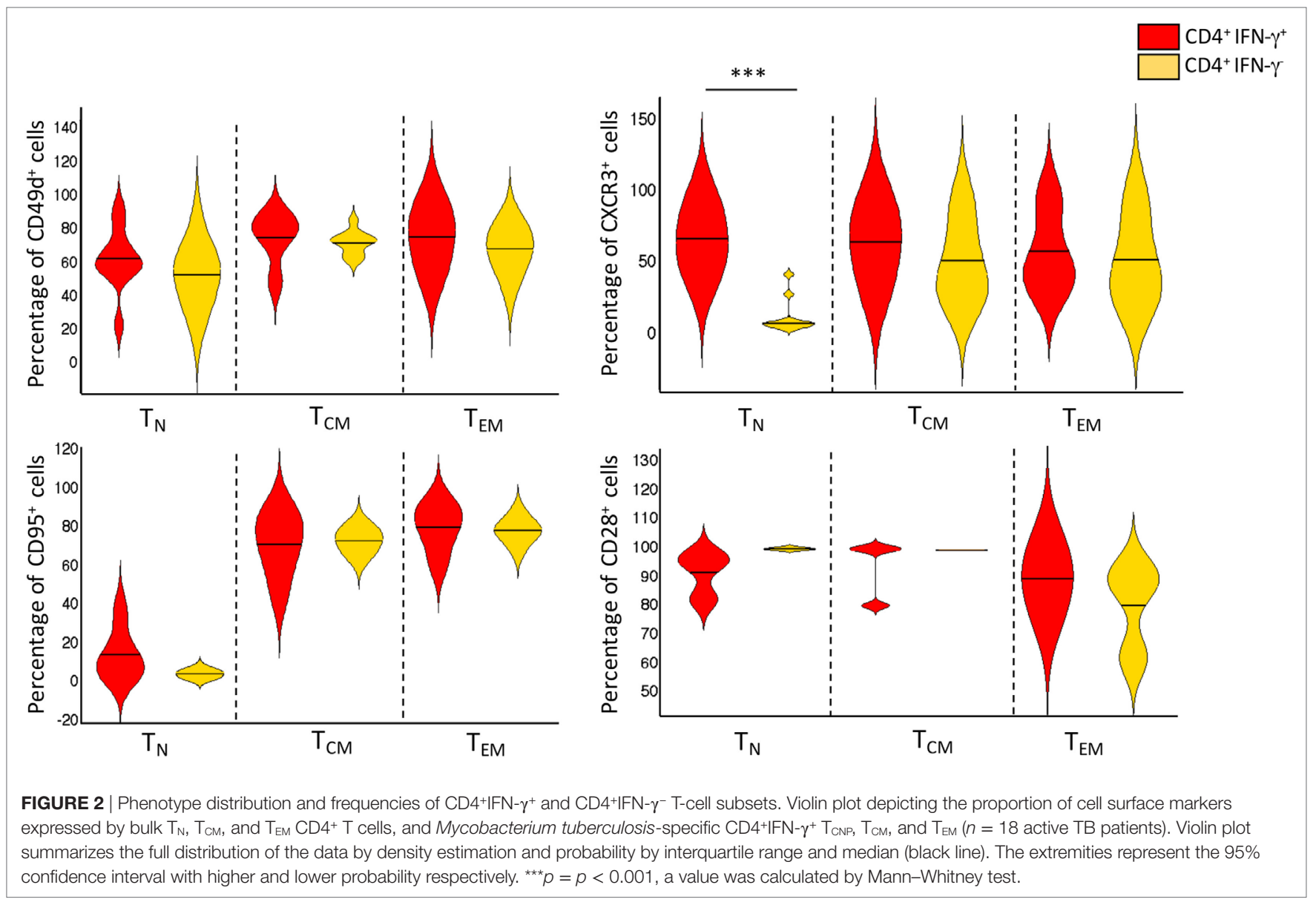

As shown in Figure 3, the expression of five T-cell-activation and -differentiation markers (CD45RA, CCR7, CD95, CD49d, CXCR3) distinguished discrete IFN- $\gamma$-producing T-cell subsets among PBMCs stimulated with ESAT-6/CFP10 antigens. As expected, the highest IFN- $\gamma$ staining intensity was detected amongst cell populations, which stained negative for both CD45RA and CCR7 and thus likely corresponding to canonical $\mathrm{T}_{\mathrm{EM}}$ cells. The $\mathrm{T}_{\mathrm{N}}$ cell subset, as identified by the expression

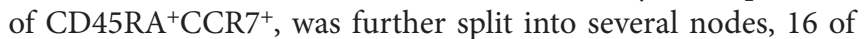
which corresponded to canonical $\mathrm{T}_{\mathrm{N}}$ cells and 17 nodes enriched for IFN- $\gamma$-producing cells, thus identifying the $\mathrm{T}_{\mathrm{CNP}}$ subset (Figure 3). The analysis of the mean fluorescence intensity further revealed that $\mathrm{CD} 4{ }^{+} \mathrm{IFN}-\gamma+\mathrm{T}_{\mathrm{CNP}}$ cells had higher expression of CCR7, CD45RA, and CXCR3, intermediate expression of CD49d and very low, if any CD95 expression. Hence, SPADE analysis confirmed that the phenotypic profile of ESAT-6/CFP10specific $\mathrm{CD} 4^{+} \mathrm{IFN}-\gamma^{+} \mathrm{T}_{\mathrm{CNP}}$ cells was markedly distinct from that of $\mathrm{T}_{\mathrm{N}}, \mathrm{T}_{\mathrm{SCM}}, \mathrm{T}_{\mathrm{CM}}$, or $\mathrm{T}_{\mathrm{EM}}$ cells (9).

We next assessed the TCR diversity of the $\mathrm{CD} 4^{+} \mathrm{T}_{\mathrm{CNP}}$ cells by flow cytometry using antibodies specific for the 24 different TCR $\beta$-chain variable (V $\beta$ ) regions, which cover $70 \%$ of the total $\mathrm{V} \beta$ repertoire in three patients. Figure 4 shows that $\mathrm{T}_{\mathrm{CNP}}$ cells had an overall broad distribution of different V $\beta$ gene segments, but some $\mathrm{V} \beta$ families (V $\beta 5.1, \mathrm{~V} \beta 7.1, \mathrm{~V} \beta 8, \mathrm{~V} \beta 12$, $\mathrm{V} \beta 13.2, \mathrm{~V} \beta 16$, and $\mathrm{V} \beta 17$ ) were similarly expressed in $\mathrm{CD} 4^{+}$
$\mathrm{T}_{\mathrm{CNP}}$ and in the most differentiated $\mathrm{CD} 4^{+} \mathrm{T}_{\mathrm{EM}}$ cells, suggesting that the CD4 $\mathrm{T}_{\mathrm{CNP}}$ cell population might have arisen in response to $M$. tuberculosis antigens that drove the generation of CD4 $\mathrm{T}_{\mathrm{EM}}$ cells, in a putative linear differentiation model (7). Of note, $M$. tuberculosis-specific IFN- $\gamma^{+} \mathrm{CD} 4^{+} \mathrm{T}_{\mathrm{EM}}$ cells had a dominant V $\beta 22$ gene expression and, V $\beta 13.1$, most likely reflecting the emergence of antigen-specific IFN- $\gamma^{+} \mathrm{CD} 4^{+}$ $\mathrm{T}$ effector cells as dominant clones during $M$. tuberculosis infection.

\section{$\mathrm{CD4}^{+} \mathbf{T}_{\mathrm{CNP}}$ Cells Recognize Multiple M. tuberculosis Antigens and Are Polyfunctional}

In addition to ESAT-6/CFP-10, antigen (Ag)85B and $\alpha$-crystallin (Acr, HspX, Rv2031c), which are expressed at different stages of M. tuberculosis infection (15) were used to stimulate PBMCs from 18 patients with active TB. As shown in Figure 5, 4-15\% of IFN- $\gamma$ producing $\mathrm{CD}^{+} \mathrm{T}$ cells specific for Ag85B in TB patients exhibited the $\mathrm{T}_{\mathrm{CNP}}$ phenotype, and a similar fraction (12-25\%) of IFN- $\gamma$-producing $\mathrm{CD}^{+} \mathrm{T}_{\mathrm{CNP}}$ cells was found in response to Acr. These results indicate that $\mathrm{CD}^{+}{ }^{+} \mathrm{T}_{\mathrm{CNP}}$ cells are a common feature of the global immune response to M. tuberculosis. In both instances, the proportion of unstimulated $\mathrm{CD} 4^{+} \mathrm{T}$ cells with a $\mathrm{T}_{\mathrm{N}}$ phenotype that produced IFN- $\gamma\left(\mathrm{T}_{\mathrm{CNP}}\right.$ cells) was $<0.01 \%$. 


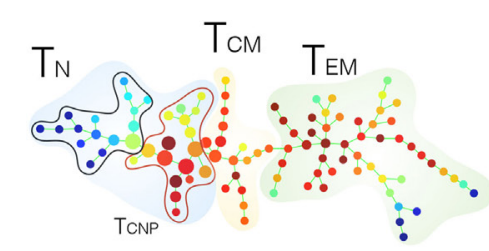

IFN- $\gamma$ staining intensity

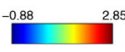

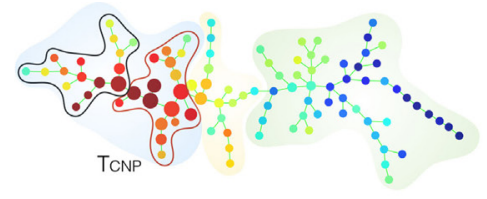

CCR7 staining intensity

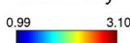

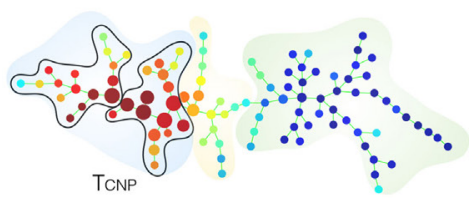

CD45RA staining intensity

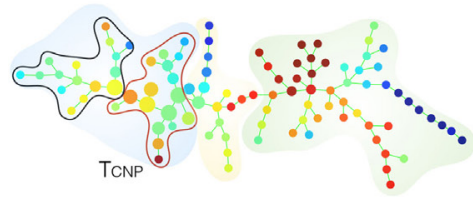

CD49d staining intensity

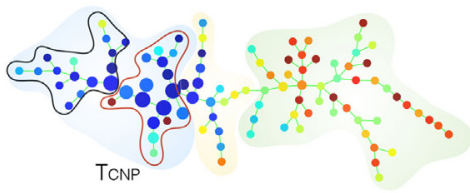

CD95 staining intensity

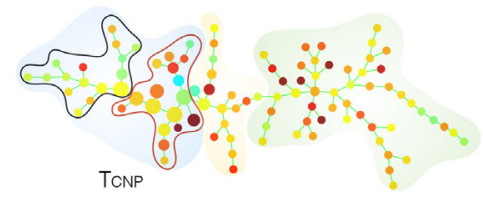

CXCR3 staining intensity

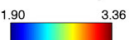

FIGURE 3 | SPADE analysis of CD4 ${ }^{+} \mathrm{T}_{\mathrm{CNP}}$ cells. CD3 ${ }^{+} \mathrm{CD} 4{ }^{+}$single cells were used to generate the SPADE tree. CD4 T-cells were analyzed for IFN- $\gamma$ expression and according to the expression of CCR7 and CD45RA expression. The color patterns indicate that the nodes contained cells that express the same surface marker. The distribution of the major populations is shown for one representative sample. The branching tree is based on the number of cells included in each node and the legend indicates the range of cell per node according to relative median fluorescence intensity of 1 out of 18 TB patients in response to ESAT6/CFP10 after $6 \mathrm{~h}$ of in vitro stimulation.

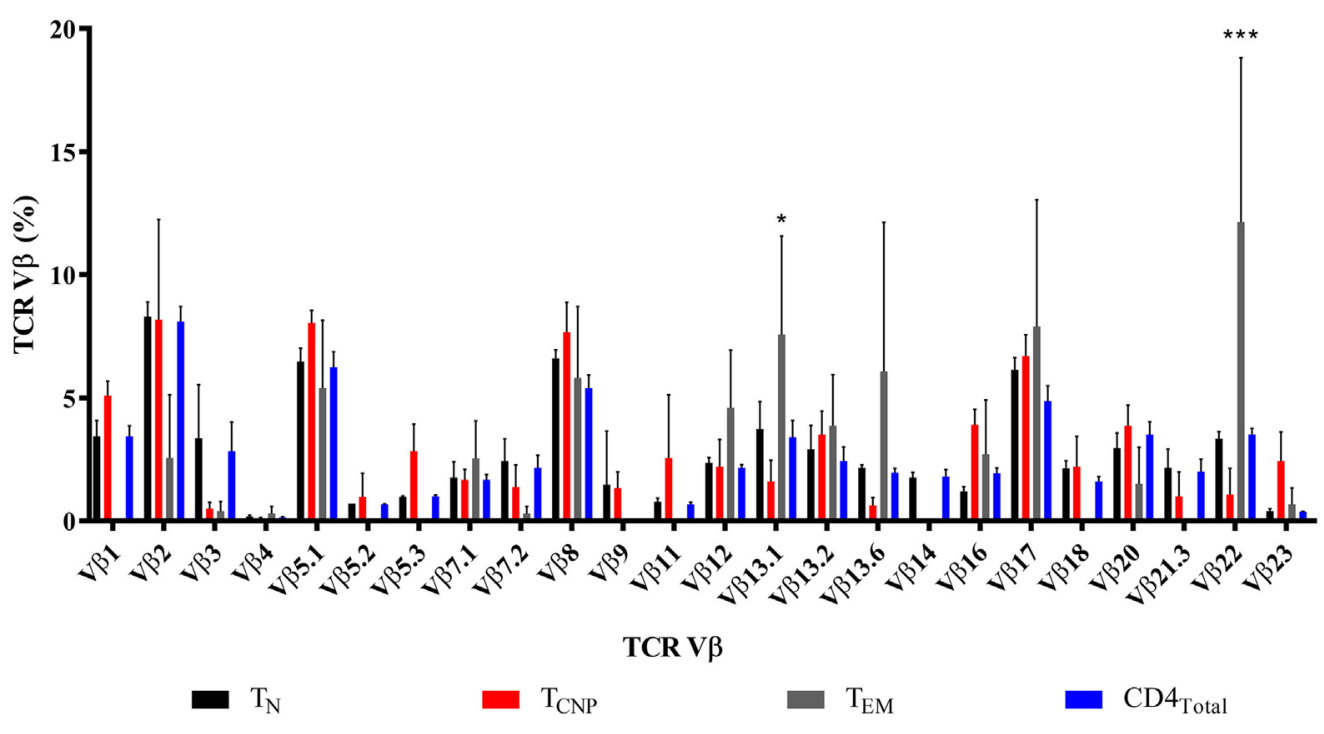

FIGURE $4 \mid T_{C N P}$ cells have a broad TCR V $\beta$ repertoire. Distribution of TCR V $\beta$ in each of the 24 TCR V $\beta$ regions assessed (horizontal axis) in the CD4 $T_{N}$, CD4 $T_{C N P}$, $\mathrm{CD}_{\mathrm{E}} \mathrm{T}_{\mathrm{EM}}$, and bulk CD4+ T-cells, analyzed on the basis of IFN- $\gamma$ production and on the expression of CCR7 and CD45RA of three representative patients with active TB. Clonogram represents the mean of the 24 TCR V $\beta$ expression of the three patients. ${ }^{*} p<0.05$ when $\mathrm{T}_{\mathrm{EM}}$ subset was compared to $\mathrm{T}_{\mathrm{CNP}}$ subset and ${ }^{\star \star \star} p<0.001$ when $\mathrm{T}_{\mathrm{EM}}$ subset was compared to the all subsets.

Similarly, we consistently failed to detect $\mathrm{CD} 4^{+} \mathrm{T}_{\mathrm{N}}$ cells making IFN- $\gamma$ among PBMC of healthy age- and sex-matched healthy $\mathrm{PPD}^{-}$control individuals (data not shown). However, following
$6 \mathrm{~h}$ stimulation of PBMCs from healthy donors with ionomycin and PMA, $0.5-4 \%$ of $\mathrm{CD}^{+} \mathrm{T}_{\mathrm{N}}$ cells expressed IFN- $\gamma$ (data not shown). 
The polyfunctionality of $\mathrm{CD}^{+}{ }^{+} \mathrm{T}_{\mathrm{CNP}}$ cells, defined as the simultaneous production of IFN- $\gamma$, IL- 2 , and TNF- $\alpha$ in response to stimulation with ESAT6/CFP-10 peptides or Ag85B or Acr proteins, was evaluated further. To this aim, we first gated on $\mathrm{CD} 4^{+}$cells expressing IFN- $\gamma$, IL- 2 , and TNF- $\alpha$ and then evaluated their surface memory phenotypes. As shown in Figure 5B, an average $60 \%$ of the polyfunctional, triple cytokine positive (IFN- $\gamma$, IL-2, and TNF- $\alpha$ ) CD4 ${ }^{+} \mathrm{T}$ cells had a $\mathrm{T}_{\mathrm{CNP}}$ phenotype, as compared to $15 \%$ with a $\mathrm{T}_{\mathrm{CM}}$ phenotype and $25 \%$ with a $\mathrm{T}_{\mathrm{EM}}$ phenotype. This indicates that the ESAT-6/CFP10-specific CD4 ${ }^{+}$ $\mathrm{T}_{\mathrm{CNP}}$ cells are differentiated polyfunctional $\mathrm{T}$-cells that differ both phenotypically and functionally from the quiescent $\mathrm{CD} 4^{+}$ $\mathrm{T}_{\mathrm{N}}$ population.

\section{$\mathrm{CD4}^{+} \mathrm{T}_{\mathrm{CNP}}$ Cell Frequencies in the Blood Correlate With Active TB Disease}

We next determined whether the $\mathrm{CD}^{+}{ }^{+} \mathrm{T}_{\mathrm{CNP}}$ population was stable over time by measuring their frequencies cross-sectionally in samples from 10 patients after completion of anti-TB therapy.

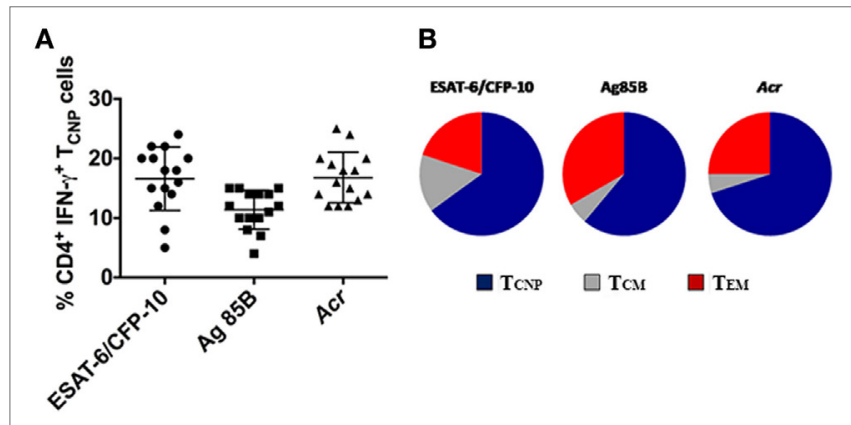

FIGURE 5 | Broad antigen repertoire and polyfunctionality of CD4+T ${ }_{\text {CNP }}$ cells. (A) Cumulative data on the frequencies of ESAT-6/CFP10, Ag85B- and Acr-specific CD4+IFN- $\gamma^{+} T_{C N P}$ cells in peripheral blood of 15 patients with active TB disease. Horizontal lines indicate the mean. (B) peripheral blood mononuclear cells were stimulated with ESAT-6/CFP10 peptides, Ag85B, and $\mathrm{Acr}$ protein antigens and CD4+ ${ }^{+}$-cell subsets simultaneously expressing IFN- $\gamma$, TNF- $\alpha$, and IL-2 were gated. Triple cytokine-positive CD4+ T cells were then gated on the basis of surface marker expression for CD45RA and CCR7 to identify relative proportions of $\mathrm{T}_{\mathrm{CM}}, \mathrm{T}_{\mathrm{CNP}}$, and $\mathrm{T}_{\mathrm{EM}}$ subsets.
As shown in Figure 6A, the proportion of $\mathrm{CD} 4^{+} \mathrm{T}_{\mathrm{CNP}}$ cells producing IFN- $\gamma$ significantly decreased in cured TB patients. Similar results were obtained upon stimulation with Ag85B and Acr antigens (data not shown). Moreover, we determined whether the $\mathrm{CD} 4^{+} \mathrm{T}_{\mathrm{CNP}}$ population was detectable in subjects with latent M. tuberculosis infection (LTBI subjects). As shown in Figure 6A, active $\mathrm{TB}$ patients had significantly more $\mathrm{T}_{\mathrm{CNP}}$ cells when compared to LTBI individuals.

For comparison, frequencies of $M$. tuberculosis-specific CD $4^{+}$ $\mathrm{T}_{\mathrm{CM}}$ (Figure 6B) and $\mathrm{T}_{\mathrm{EM}}$ cells (Figure 6C) were very similar in the three tested groups, without significant difference among them.

To support the above data, we evaluated frequencies of IFN- $\gamma$ producing naïve $\left(\mathrm{CD} 45 \mathrm{RA}^{+} \mathrm{CCR} 7^{+} \mathrm{CD} 28^{+} \mathrm{CD} 95^{-}\right) \mathrm{CD} 4^{+} \mathrm{T}$ cells in a different cohort of 10 patients with active TB before the initiation of therapy (TB-0), compared with blood samples from the same patients taken 6 months later, i.e., at the end of therapy (TB-6). As shown in Figure S2 in Supplementary Material, the frequency of the presumptive $\mathrm{T}_{\mathrm{N}}$ producing IFN- $\gamma$ population declined in all tested patients after therapy, strongly supporting previous data obtained in patients with cured TB disease.

All together, these results indicate that $M$. tuberculosis-specific $\mathrm{CD} 4^{+} \mathrm{T}_{\mathrm{CNP}}$ cells are a novel $\mathrm{T}$ cell subset that is associated with active $\mathrm{TB}$ disease.

\section{DISCUSSION}

$\mathrm{CD}^{+}{ }^{+} \mathrm{T}$-cell-mediated protection against a wide range of pathogenic microorganisms is dependent on different types of Th cells endowed with distinct effector functions (16).

Our results identify a novel human memory CD4 T cell subset with an unorthodox, $\mathrm{T}_{\mathrm{N}}$-like phenotype, which is involved in the human immune response to mycobacteria, and which correlates with the presence of active TB disease during infection by $M$. tuberculosis. Following curative TB treatment, the size of this $\mathrm{T}$ cell subset significantly decreased, suggesting that these cells are markers of disease activity. Accordingly, LTBI subjects had a lower proportion of this CD4 T cell population in the peripheral blood.

This novel human $\mathrm{T}$ cell subset was discovered during our studies to quantitate the proportion of functional CD4 ${ }^{+} \mathrm{T}$ cells,
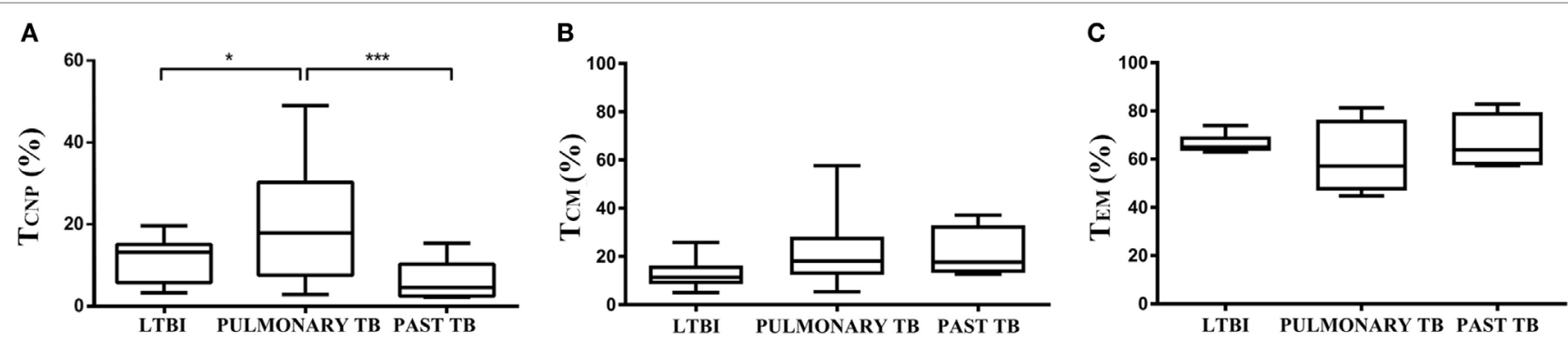

FIGURE 6 | CD4+ T $_{C N P}$ cells correlate with active TB disease. Summary cumulative data of the frequency of CD4 ${ }^{+}$IFN- $\boldsymbol{\gamma}^{+} \mathrm{T}_{\mathrm{CNP}}$ cells $(\mathbf{A})$, $\mathrm{T}_{\mathrm{CM}}$ (B), and $\mathrm{T}_{\mathrm{EM}}$ (C) cells in patients with active TB, longitudinally assessed before the initiation of therapy (TB-0), compared to the same patients at the end of therapy, TB-6, and latent tuberculosis infection subjects. The boxes represent interquartile ranges; the line in the middle of the box represents the median, and minimum/maximum values are shown. Data are representative of three independent experiments. $p$-values were calculated by Kruskal-Wallis test. ${ }^{*} p<0.05$ and ${ }^{* \star *} p<0.001$ were considered statistically significant. 
using standard $6 \mathrm{~h}$ in vitro stimulation with three different mycobacterial antigens (CFP10/Esat-6, Ag85, and Acr proteins) followed by intracellular FACS analysis to determine memory subset phenotypes of antigen-specific $\mathrm{CD} 4^{+} \mathrm{T}$-cells, based on their expression of CCR7 and CD45RA (7). As expected, the majority of IFN- $\gamma^{+} \mathrm{CD} 4^{+} \mathrm{T}$ cells responding to ESAT-6/CFP-10 in patients with active $\mathrm{TB}$ disease had a $\mathrm{T}_{\mathrm{EM}}$ phenotype, while $10-28 \%$ of IFN $-\gamma^{+} \mathrm{CD} 4^{+} \mathrm{T}$ cells displayed a $\mathrm{T}_{\mathrm{CM}}$ phenotype. Unexpectedly, we detected a sizeable cell population that phenotypically expressed a naive like phenotype yet produced antigen-induced IFN $-\gamma^{+}$. We termed this population $\mathrm{CD} 4^{+} \mathrm{T}_{\mathrm{CNP}}$ due to their capacity to rapidly secrete multiple cytokines while expressing a naive phenotype.

IFN- $\gamma$ profiles of CD4 $\mathrm{T}_{\mathrm{CNP}}$ cells were defined in more detail using additional cell surface markers and the SPADE algorithm-tool, which distinguishes cell subsets by clustering on the base of surface antigen expression identified by a color gradient. These analyses revealed that IFN $-\gamma^{+} \mathrm{CD} 4^{+} \mathrm{T}_{\mathrm{CNP}}$ cells were further marked by expression of CCR7, CD45RA, CD28, CD49d and CXCR3, and very low, if any CD95 expression. This indicates that the phenotypic profile of ESAT-6/CFP10specific CD $4^{+} I F N-\gamma^{+} T_{\mathrm{CNP}}$ cells is distinct from that of $\mathrm{T}_{\mathrm{N}}, \mathrm{T}_{\mathrm{SCM}}$, $\mathrm{T}_{\mathrm{CM}}$, or $\mathrm{T}_{\mathrm{EM}}$ cells. Moreover, analysis of TCR-V $\beta$ gene usage showed that $\mathrm{T}_{\mathrm{CNP}}$ cells were not oligoclonal, but displayed highly heterogeneous $\mathrm{V} \beta$ gene segment usage. V $\beta 5.1, \mathrm{~V} \beta 7.1$, $\mathrm{V} \beta 8, \mathrm{~V} \beta 12, \mathrm{~V} \beta 13.2, \mathrm{~V} \beta 16$, and $\mathrm{V} \beta 17$ families were similarly expressed among $\mathrm{CD} 4^{+} \mathrm{T}_{\mathrm{CNP}}$ and $\mathrm{CD} 4^{+} \mathrm{T}_{\mathrm{EM}}$ cells, suggesting that the $\mathrm{CD} 4 \mathrm{~T}_{\mathrm{CNP}}$ cell population might have arisen in response to $M$. tuberculosis antigens that drove the generation of highly differentiated CD4 $\mathrm{T}_{\mathrm{EM}}$ cells (7). Of note, M. tuberculosisspecific IFN- $\gamma^{+} \mathrm{CD}^{+} \mathrm{T}_{\mathrm{EM}}$ cells showed expanded V $\beta 13.1$ and $\mathrm{V} \beta 22$ regions, likely reflecting the emergence of antigenspecific IFN $-\gamma^{+} \mathrm{CD} 4^{+} \mathrm{T}$ effector cells as dominant clones during $M$. tuberculosis infection. Interestingly, previous studies in macaques have demonstrated that the Ag-specific CD4 $4^{+} \mathrm{IFN}-$ $\gamma^{+}$against $M$. tuberculosis is characterized by the emergence of few dominant clones, which undergo major recall expansion and rapidly traffic to the lungs (17). However, additional data are needed due to the limited number of individuals that was tested for TCR V $\beta$ repertoire.

$\mathrm{CD}^{+} \mathrm{T}$ cells with a $\mathrm{T}_{\mathrm{CNP}}$ phenotype accounted for a large proportion, as an average $60 \%$ of triple cytokine-positive $\mathrm{CD}^{+}$ T-cells had a $\mathrm{T}_{\mathrm{CNP}}$ phenotype cells, compared to only $15 \%$ expressing a $\mathrm{T}_{\mathrm{CM}}$ phenotype and $25 \%$ expressing a $\mathrm{T}_{\mathrm{EM}}$ phenotype. This indicates that the ESAT-6/CFP10-specific $\mathrm{CD} 4^{+} \mathrm{T}_{\mathrm{CNP}}$ cells are differentiated polyfunctional $\mathrm{T}$ cells that differ both phenotypically and functionally from the quiescent $\mathrm{CD} 4^{+} \mathrm{T}_{\mathrm{N}}$ population.

Recent studies have shown that polyfunctional $\mathrm{T}$ cells provide immune protection in viral infections such as HIV (18) while they are induced in response to a novel tuberculosis vaccine and their role is under investigation (19). They also correlated with protection in a murine Leishmania model (5) and in mouse models of TB vaccine-induced protection $(20,21)$. However, their role during human $M$. tuberculosis infection is controversial and less clear, and these cells do not seem to have the same protection-associated role as observed in chronic viral infections (22). Different authors have recently shown that polyfunctional $\mathrm{T}$ cell responses result from a sequential release of cytokines, with very short periods of time in which cells secrete multiple cytokines simultaneously. These results, along with differences in methodological aspects such as culture time, the use of peptide pools or fusion proteins compared to recombinant proteins used, the criteria to select TB patients, might explain the discordant results, and should be taken into account.

Additional work will obviously be needed to address whether the developmental fate of $\mathrm{CD} 4{ }^{+} \mathrm{T}_{\mathrm{CNP}}$ cells intersects with that of any other subset, and in particular with $\mathrm{CD}^{+}$ $\mathrm{T}_{\mathrm{SCM}}$ cells, despite the differential expression of certain surface markers, such as CD95 [as shown here and in Ref. (16)]. Our results reported here are in agreement with data on $\mathrm{CD}^{+} \mathrm{T}$ cells reported by Nikolich-Zugich and coworkers (23) showing that West Nile virus infection resulted in the expansion of $\mathrm{CD}^{+} \mathrm{T}$ cells producing IFN- $\gamma$ while expressing a naive phenotype, which were termed $\mathrm{T}_{\mathrm{MNP}}$ cells. These $\mathrm{T}_{\mathrm{MNP}}$ cells were specifically present in symptomatic subjects, suggesting that their frequency and numbers correlated with the severity of acute viral infection. Finally, also Scriba et al. (24) have identified M. tuberculosis-specific $\mathrm{CD} 4^{+} \mathrm{T}$ cells that were induced by primary $M$. tuberculosis infection and displayed a $\mathrm{T}_{\text {SCM }}$ phenotype while also being capable of producing IL-2, TNF- $\alpha$, and IFN- $\gamma$ and, in agreement with the $\mathrm{T}_{\mathrm{CNP}}$ population we have described here, which predominantly expresses CXCR3.

Whether or not the $\mathrm{CD} 4^{+} \mathrm{T}_{\mathrm{CNP}}$ cells here described represent a defined and stable $\mathrm{T}$ cell subset (25-27) or rather a transient population, and how it is related or not to $\mathrm{T}_{\mathrm{SCM}}$ cells remains to be determined. $\mathrm{CD}^{+} \mathrm{T}_{\mathrm{CNP}}$ cells express CXCR3 and CD49d, which allow them to rapidly traffic to sites of $M$. tuberculosis infection and engage in the control of bacterial replication by virtue of their ability to secrete the type- 1 cytokines, IFN- $\gamma$, and TNF- $\alpha$, which are well known players in antimycobacterial protective immune responses. Moreover, as their number also correlates with the presence of active TB disease, they might also serve as a TB specific biomarker of disease as well as a successful response to chemotherapy even if this finding requires to be validated in detail in follow up studies with dense sampling during TB treatment.

\section{ETHICS STATEMENT}

The study was approved by the Ethical Committee of the University Hospital in Palermo (approval number 13/2013) and of "L. Spallanzani" National Institute of Infectious Diseases (INMI), approval number 72/2015.

\section{AUTHOR CONTRIBUTIONS}

Conceived and designed the experiments and wrote the paper: FD and NC. Performed the experiments: CM, SB, VO, and MM. Analyzed the data: FD, NC, VO, and MM. Enrolled the patients and collected the clinical information: DG and FP. Supervised the laboratory collection of the clinical samples: DG. Supervised the paper: TO, SJ, and DG. 


\section{ACKNOWLEDGMENTS}

This work was supported by grants from the Ricerca Corrente of INMI, the Norwegian Agency for Development Cooperation (NORAD) through Tuberculosis Vaccine Initiative(contract no. 1001143436007833), the European Commission within the $7^{\text {th }}$ Framework Programme, NEWTBVAC (contract no. HEALTH-F3-2009-241745), the Horizon2020 Programmes TBVAC2020 (contract no. 643381), and EMI-TB (contract no. 643558). The text represents the authors' views and does not necessarily represents position of the European Commission, which will not be liable for the use made of such information. We deeply thank at INMI, the research nurse Gilda Cuzzi, MPH, who helped in the enrollment of patients and collection of clinical data and the research technician Valentina Vanini, MLT, who collected the clinical samples. We also thank Tom Scriba for sharing unpublished data. This paper is dedicated to the memory of our young, wonderful colleague, and friend, SB, who recently passed away after fighting cancer.

\section{REFERENCES}

1. Cooper AM. Cell-mediated immune responses in tuberculosis. Annu Rev Immunol (2009) 27:393-422. doi:10.1146/annurev.immunol.021908. 132703

2. Harari A, Rozot V, Bellutti Enders F, Perreau M, Stalder JM, Nicod LP, et al. Dominant TNF- $\alpha+$ Mycobacterium tuberculosis-specific CD4+ T cell responses discriminate between latent infection and active disease. Nat Med (2011) 17(3):372-6. doi:10.1038/nm.2299

3. Walzl G, Ronacher K, Hanekom W, Scriba TJ, Zumla A. Immunological biomarkers of tuberculosis. Nat Rev Immunol (2011) 11(5):343-54. doi:10.1038/ nri2960

4. Caccamo N, Guggino G, Joosten SA, Gelsomino G, Di Carlo P, Titone L, et al. Multifunctional CD4(+) T cells correlate with active Mycobacterium tuberculosis infection. Eur J Immunol (2010) 40(8):2211-20. doi:10.1002/ eji.201040455

5. Darrah PA, Patel DT, De Luca PM, Lindsay RW, Davey DF, Flynn BJ, et al. Multifunctional TH1 cells define a correlate of vaccine-mediated protection against Leishmania major. Nat Med (2007) 13(7):843-50. doi:10.1038/nm1592

6. Ottenhoff TH. New pathways of protective and pathological host defense tomycobacteria. Trends Microbiol (2012) 20(9):419-28. doi:10.1016/j.tim. 2012.06.002

7. Lanzavecchia A, Sallusto F. Understanding the generation and function of memory T cell subsets. Curr Opin Immunol (2005) 17(3):326-32. doi:10.1016/j. coi.2005.04.010

8. Wang X, Cao Z, Jiang J, Niu H, Dong M, Tong A, et al. Association of mycobacterial antigen-specific CD4(+) memory T cell subsets with outcome of pulmonary tuberculosis. J Infect (2010) 60(2):133-9. doi:10.1016/j.jinf. 2009.10.048

9. Mahnke YD, Brodie TM, Sallusto F, Roederer M, Lugli E. The who's who of T-cell differentiation: human memory T-cell subsets. Eur J Immunol (2013) 43(11):2797-809. doi:10.1002/eji.201343751

10. Goletti D, Sanduzzi A, Delogu G. Performance of the tuberculin skin test and interferon- $\gamma$ release assays: an update on the accuracy, cutoff stratification, and new potential immune-based approaches. J Rheumatol Suppl (2014) 91:24-31. doi:10.3899/jrheum.140099

11. Goletti D, Lee MR, Wang JY, Walter N, Ottenhoff THM. Update on tuberculosis biomarkers: from correlates of risk, to correlates of active disease and of cure from disease. Respirology (2018) 5:455-66. doi:10.1111/resp.13272

12. Franken KL, Hiemstra HS, van Meijgaarden KE, Subronto Y, den Hartigh J, Ottenhoff TH, et al. Purification of his-tagged proteins by immobilized chelate affinity chromatography: the benefits from the use of organic solvent. Protein Expr Purif (2000) 18(1):95-9. doi:10.1006/prep.1999.1162

\section{SUPPLEMENTARY MATERIAL}

The Supplementary Material for this article can be found online at https://www.frontiersin.org/articles/10.3389/fimmu.2018.01119/ full\#supplementary-material.

FIGURE S1 | CD4 ${ }^{+}$T-cells with a naive phenotype (CD4 ${ }^{+} T_{\text {CNP }}$ cells) are found among IFN- $\gamma^{\text {low }} \mathrm{CD} 4^{+} \mathrm{T}$ cells in patients with active TB. Flow cytometry analysis of peripheral blood mononuclear cells from one representative TB patient. Cells were stimulated with ESAT6/CFP10 peptides for $6 \mathrm{~h}$ as described in the Section "Materials and Methods" and analysis of cell surface marker expression was differentially performed on the gated CD4+IFN- $\gamma^{\text {high }}$ and CD4+ IFN- $\gamma^{\text {low }}$ populations, demonstrating that the former expresses a $T_{E M}$ phenotype and the latter a $T_{C N P}$ phenotype.

FIGURE S2 | Interferon- $\gamma$ (IFN- $\gamma$ )-producing naïve CD4+ T cells are linked to active TB disease. Quantification of IFN- $\gamma$-producing naïve

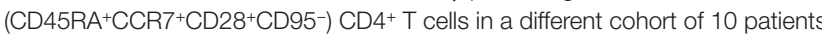
with active TB disease, longitudinally assessed before the initiation of therapy (TB-0) compared with blood samples from the same patients taken 6 months later, i.e. at the end of therapy (TB-6).

13. Cossarizza A, Chang HD, Radbruch A, Akdis M, Andrä I, Annunziato F, et al. Guidelines for the use of flow cytometry and cell sorting in immunological studies. Eur J Immunol (2017) 47(10):1584-797. doi:10.1002/ eji.201646632

14. Qiu P, Simonds EF, Bendall SC, Gibbs KD Jr, Bruggner RV, Linderman MD, et al. Extracting a cellular hierarchy from high-dimensional cytometry data with SPADE. Nat Biotechnol (2011) 29(10):886-91. doi:10.1038/nbt.1991

15. Leyten EM, Lin MY, Franken KL, Friggen AH, Prins C, van Meijgaarden KE, et al. Human T-cell responses to 25 novel antigens encoded by genes of the dormancy regulon of Mycobacterium tuberculosis. Microbes Infect (2006) 8(8):2052-60. doi:10.1016/j.micinf.2006.03.018

16. Sallusto F. Heterogeneity of human CD4(+) T cells against microbes. Annu Rev Immunol (2016) 20(34):317-34. doi:10.1146/annurev-immunol032414-112056

17. Du G, Chen CY, Shen Y, Qiu L, Huang D, Wang R, et al. TCR repertoire, clonal dominance, and pulmonary trafficking of mycobacterium-specific CD4+ and CD8+ T effector cells in immunity against tuberculosis. J Immunol (2010) 185:3940-7. doi:10.4049/jimmunol.1001222

18. Almeida JR, Price DA, Papagno L, Arkoub ZA, Sauce D, Bornstein E, et al. Superior control of HIV-1 replication by $\mathrm{CD}^{+} \mathrm{T}$ cells is reflected by their avidity, polyfunctionality, and clonal turnover. J Exp Med (2007) 204:2473-85. doi:10.1084/jem.20070784

19. Scriba TJ, Tameris M, Mansoor N, Smit E, van der Merwe L, Isaacs F, et al. Modified vaccinia Ankara-expressing Ag85A, a novel tuberculosis vaccine, is safe in adolescents and children, and induces polyfunctional CD4 $^{+}$T cells. Eur J Immunol (2010) 40:279-90. doi:10.1002/eji.200939754

20. Abel B, Tameris M, Mansoor N, Gelderbloem S, Hughes J, Abrahams D, et al. The novel tuberculosis vaccine, AERAS-402, induces robust and polyfunctional $\mathrm{CD}^{+}$and $\mathrm{CD}^{+} \mathrm{T}$ cells in adults. Am J Respir Crit Care Med (2010) 181:1407-17. doi:10.1164/rccm.200910-1484OC

21. Soares AP, Scriba TJ, Joseph S, Harbacheuski R, Murray RA, Gelderbloem SJ, et al. Bacillus Calmette-Guerin vaccination of human newborns induces $\mathrm{T}$ cells with complex cytokine and phenotypic profiles. J Immunol (2008) 180:3569-77. doi:10.4049/jimmunol.180.5.3569

22. Newell EW, Sigal N, Bendall SC, Nolan GP, Davis MM. Cytometry by timeof-flight shows combinatorial cytokine expression and virus-specific cell niches within a continuum of CD8+ T cell phenotypes. Immunity (2012) 36(1):142-52. doi:10.1016/j.immuni.2012.01.002

23. Nikolich-Zugich J. Ageing and life-long maintenance of T-cell subsets in the face of latent persistent infections. Nat Rev Immunol (2008) 8(7):512-22. doi:10.1038/nri2318

24. Mpande CAM, Dintwe OB, Musvosvi M, Mabwe S, Bilek N, Hatherill M, et al. Functional, antigen-specific stem cell memory $\left(\mathrm{T}_{\mathrm{SCM}}\right) \mathrm{CD} 4^{+} \mathrm{T}$ cells are 
induced by human Mycobacterium tuberculosis infection. Front Immunol (2018) (9):324. doi:10.3389/fimmu.2018.00324

25. Pulko V, Davies JS, Martinez C, Lanteri MC, Busch MP, Diamond MS, et al. Human memory $\mathrm{T}$ cells with a naive phenotype accumulate with aging and respond to persistent viruses. Nat Immunol (2016) 17(8):966-75. doi:10.1038/ni.3483

26. Song K, Rabin RL, Hill BJ, De Rosa SC, Perfetto SP, Zhang HH, et al. Characterization of subsets of CD4+ memory $\mathrm{T}$ cells reveals early branched pathways of T cell differentiation in humans. Proc Natl Acad Sci U S A (2005) 102(22):7916-21. doi:10.1073/pnas.0409720102

27. Haines CJ, Giffon TD, Lu LS, Lu X, Tessier-Lavigne M, Ross DT, et al. Human $\mathrm{CD} 4+\mathrm{T}$ cell recent thymic emigrants are identified by protein tyrosine kinase 7 and have reduced immune function. JExp Med (2009) 206(2):275-85. doi:10.1084/jem.20080996
Conflict of Interest Statement: The authors declare that the research was conducted in the absence of any commercial or financial relationships that could be construed as a potential conflict of interest.

The reviewer SW and handling Editor declared their shared affiliation.

Copyright ( 2018 Orlando, La Manna, Goletti, Palmieri, Lo Presti, Joosten, La Mendola, Buccheri, Ottenhoff, Dieli and Caccamo. This is an open-access article distributed under the terms of the Creative Commons Attribution License (CC $B Y$ ). The use, distribution or reproduction in other forums is permitted, provided the original author(s) and the copyright owner are credited and that the original publication in this journal is cited, in accordance with accepted academic practice. No use, distribution or reproduction is permitted which does not comply with these terms. 